Ocena grubości błony śluzowej podniebienia przy użyciu tomografii komputerowej wiązki stożkowej

\section{Assessment of the thickness of the palatal mucosa using cone-beam computed tomography}

\author{
Karolina Wojas ${ }^{1}$ ABCDF (ORCID ID: 0000-0002-8798-6858) \\ Kinga Grzegocka1 ABC (ORCID ID: 0000-0002-9177-9544) \\ Małgorzata Pihut ${ }^{2}$ EF(ORCID ID: 0000-0002-0239 4328) \\ Wojciech Stós ${ }^{1}$ EF (ORCID ID: 0000-0003-4836-5562) \\ Marta Gibas-Stanek1BC (ORCID ID: 0000-0002-9837-0223)
}

\begin{abstract}
Wkład autorów: $\mathbf{A}$ Plan badań $\mathbf{B}$ Zbieranie danych $\mathbf{C}$ Analiza statystyczna $\mathbf{D}$ Interpretacja danych $\mathbf{E}$ Redagowanie pracy $\mathbf{F}$ Wyszukiwanie piśmiennictwa
\end{abstract}

Authors' Contribution: A Study design B Data Collection $\mathbf{C}$ Statistical Analysis $\mathbf{D}$ Data Interpretation E Manuscript Preparation $\mathbf{F}$ Literature Search

${ }^{1}$ Katedra Ortodoncji, Instytut Stomatologii, Wydział Lekarski, Uniwersytet Jagielloński, Collegium Medicum, Kraków

Department of Orthodontics, Dental Institute, Faculty of Medicine, Jagiellonian University, Medical College, Cracow

${ }^{2}$ Katedra Protetyki Stomatologicznej, Instytut Stomatologii, Wydział Lekarski, Uniwersytet Jagielloński, Collegium Medicum, Kraków Department of Prosthetics, Dental Institute, Faculty of Medicine, Jagiellonian University, Medical College, Cracow

\section{Streszczenie}

W procesie leczenia ortodonci coraz chętniej sięgają po miniimplanty ortodontyczne. Ze względu na łatwy dostęp, niskie ryzyko uszkodzenia struktur anatomicznych oraz obecność dziąsła skeratynizowanego podniebienie jest najbardziej korzystnym miejscem do wprowadzenia miniśrub. Przy wyborze lokalizacji miniimplantu należy zwrócić uwagę

\begin{abstract}
Orthodontic mini-implants are increasingly often used by orthodontists. Thanks to the easy access, low risk of damage to other anatomical structures and the presence of keratinised gingiva, the palate is the most advantageous place for the insertion of mini-screws. When choosing a location for a mini-implant on the palate, the amount of the bone and
\end{abstract}

Adres do korespondencji/Correspondence address:

Karolina Wojas

Katedra i Zakład Ortodoncji, Instytut Stomatologii, Uniwersytet Jagielloński Collegium Medicum w Krakowie ul. Montelupich 4, 31-155 Kraków

e-mail: karolina.wojass@gmail.com

\title{
@(1)@(2)
}

Copyright: (C) 2005 Polish Orthodontic Society. This is an Open Access journal, all articles are distributed under the terms of the Creative Commons Attribution-NonCommercial-ShareAlike 4.0 International (CC BY-NC-SA 4.0) License (http://creativecommons.org/licenses/by-nc-sa/4.0/), allowing third parties to copy and redistribute the material in any medium or format and to remix, transform, and build upon the material, provided the original work is properly cited and states its license. 
na ilość kości oraz grubość tkanek miękkich znajdujących się w danym miejscu. Cel. Celem badania była ocena grubości tkanek miękkich pokrywających centralną część podniebienia oraz porównanie ich wymiaru w zależności od płci i wieku pod kątem doboru odpowiedniego miejsca do umieszczenia miniimplantów. Materiał i metody. W badaniu przeanalizowano 105 tomografii komputerowych wiązki stożkowej pacjentów (55 kobiet, 50 mężczyzn, średnia wieku 28 lat), na których mierzono grubość błony śluzowej podniebienia w określonych 12 punktach. Punkty znajdowały się 3, 6, 10, $18 \mathrm{~mm}$ za tylną ścianą otworu przysiecznego oraz w odległości $0,3,6 \mathrm{~mm}$ bocznie od linii szwu podniebiennego. Uzyskane dane poddano analizie statystycznej w celu oceny średniej grubości błony śluzowej podniebienia, oceny zależności grubości tkanek miękkich w stosunku do lokalizacji na podniebieniu oraz w stosunku do płci i wieku. Wyniki. Stwierdzono, że im dalej ku tyłowi od otworu przysiecznego oraz im bliżej linii pośrodkowej podniebienia, tym błona śluzowa staje się cieńsza i tworzy dogodniejsze warunki do umieszczenia miniimplantów. Grubość tkanek miękkich jest większa u mężczyzn niż u kobiet w obszarze podniebienia $18 \mathrm{~mm}$ za dystalnym brzegiem otworu przysiecznego. Wnioski. W badaniu stwierdzono, że grubość tkanek miękkich pokrywających centralną część podniebienia różni się w zależności od płci, wieku i lokalizacji na podniebieniu. (Wojas K, Grzegocka K, Pihut M, Stós W, Gibas-Stanek M. Ocena grubości błony śluzowej podniebienia przy użyciu tomografii komputerowej wiązki stożkowej. Forum Ortod 2021; 17 (3): 173-84).

Nadesłano: 07.04.2021

Przyjęto do druku: 22.09.2021

https://doi.org/10.5114/for.2021.110500

Słowa kluczowe: podniebienie, CBCT, błona śluzowa, miniimplanty, zakotwienie szkieletowe

\section{Wprowadzenie}

Miniimplanty ortodontyczne są wykorzystywane przez ortodontów coraz częściej, zwłaszcza w przypadkach wymagających maksymalnego zakotwienia sił ortodontycznych (1). Najczęściej wprowadza się je w przestrzeń międzykorzeniową zębów, okolicę zatrzonowcową żuchwy oraz na podniebieniu. Ze względu na łatwy dostęp, niskie ryzyko uszkodzenia innych struktur anatomicznych oraz obecność dziąsła skeratynizowanego podniebienie jest najbardziej korzystnym miejscem do wprowadzenia miniśrub (2-4). Ponadto taka lokalizacja wyklucza kolizję przesuwanych zębów z miniimplantami (5). Polecana jest zwłaszcza w przypadkach dystalizacji i mezjalizacji zębów bocznych, intruzji zębów oraz pociągania zębów zatrzymanych (6).

W celu uzyskania największej stabilności implantów należy brać pod uwagę zarówno grubość kości zbitej, jak soft tissues should be considered. Aim. The aim of the study was to assess the thickness of the soft tissues covering the central part of the palate and to compare their dimensions depending on the sex and age in terms of selecting the appropriate place for the placement of mini-implants. Material and methods. The study analysed 105 cone-beam computed tomography scans of patients (55 women, 50 men, mean age 28 years), and the mucosal thickness was measured in 12 specific points. The points were located at a distance of $3,6,10,18 \mathrm{~mm}$ from the distal margin of the incisive foramen and 0,3 and $6 \mathrm{~mm}$ laterally to the palatal suture. The obtained data were statistically analysed to evaluate the mean thickness of the palatal mucosa, to assess the relationship between the soft tissue thickness and the location, and in relation to sex and age. Results. It has been found that the further to the back of the incisive foramen and the closer to the palatal midline, the thinner the mucosa and better conditions for the placement of mini-implants. The soft tissue thickness in men is greater than in women in the area of the palate $18 \mathrm{~mm}$ behind the distal margin of the incisive foramen. Conclusions. The study showed that the thickness of the soft tissues covering the central part of the palate varied with the sex, age and location on the palate. (Wojas K, Grzegocka K, Pihut M, Stós W, Gibas-Stanek M. Assessment of the thickness of the palatal mucosa using cone-beam computed tomography. Orthod Forum 2021; 17 (3): 173-84).

Received: 07.04.2021

Accepted: 22.09.2021

https://doi.org/10.5114/for.2021.110500

Key words: palate, mucosa, CBCT, mini-implants, skeletal anchorage

\section{Introduction}

Orthodontic mini-implants are increasingly often used by orthodontists, especially in cases requiring maximum anchorage for orthodontic forces (1). They are most often inserted between the roots of teeth, the mandible's retromolar area, and into the palate. Thanks to the easy access, low risk of damage to other anatomical structures and presence of keratinised gingiva, the palate is the most advantageous place for the insertion of mini-screws (2-4). Moreover, such location excludes the problem of collision of moving teeth and mini-implants (5). This location of miniscrews is especially recommended in cases of distalisation and mesialisation of the lateral teeth, teeth intrusion and traction of impacted teeth (6).

In order to obtain the greatest implant stability, both the thickness of the compact bone and the mucosal thickness should be taken into consideration. According to the research by Kim et al., a smaller amount of mucosa is more 
Assessment of the thickness of the palatal mucosa using cone-beam computed tomography

i grubość błony śluzowej. Według badań Kim i wsp. korzystniej jest, gdy błona jest cieńsza (7). Znajomość grubości tkanki miękkiej ułatwia również dobór odpowiedniej długości miniimplantu oraz długości jego kołnierza (8). Jak podają Kyung i wsp., implant powinien penetrować kość co najmniej na głębokość 6 mm (1).

Istnieją różne metody oceny grubości błony śluzowej, są to: pomiar przy wykorzystaniu narzędzia endodontycznego czy sondy periodontologicznej po wcześniejszym znieczuleniu albo zastosowanie ultrasonografu (USG) (9-11). Badanie z wykorzystaniem USG jest mało inwazyjne i proste do wykonania, jednak jak donoszą Müller i wsp. to badanie jest wrażliwe na technikę wykonania i jest mniej wiarygodne, zwłaszcza w przypadku tkanek o większej grubości (12).

Na początku XXI w. do oceny grubości błony śluzowej pokrywającej wyrostki zębodołowe i podniebienie twarde zaczęto wykorzystywać tomografię komputerową (13-16). CBCT (Cone Beam Computed Tomography) - tomografia komputerowa wiązki stożkowej początkowo wprowadzona do oceny kości okolicy szczęko-twarzowej - z biegiem czasu dzięki swej wielozadaniowości stała się nieodłącznym narzędziem w rękach stomatologów (17). W ostatnim czasie przedstawiono nową metodę tomografii komputerowej wiązki stożkowej tkanek miękkich, która pozwala na dokładną ocenę grubości błony śluzowej, przy zachowaniu wartości pomiaru podobnej do tej, którą uzyskano w innych metodach badania, gdzie wykorzystywano pomiary fizyczne, takie jak narzędzie endodontyczne ze stoperem lub sondę periodontologiczną $(9,11,16,18)$.

Dotychczasowe badania oceniały błonę śluzową głównie w bocznej części podniebienia i miały służyć określeniu najlepszego miejsca poboru przeszczepu łącznotkankowego. To badanie zaprojektowano w związku z coraz większą popularnością systemów wykorzystywanych do wzmocnienia zakotwienia wspartych na miniimplantach osadzonych w okolicy szwu podniebiennego.

\section{Cel}

Celem badania była ocena grubości tkanek miękkich pokrywających centralną część podniebienia, w zależności od płci i wieku, pod kątem doboru odpowiedniego miejsca do umieszczenia miniimplantów.

\section{Materiał i metody}

\section{Materiał badań. Charakterystyka badanej grupy}

W badaniu retrospektywnym analizowano tomografie komputerowe wiązki stożkowej 509 pacjentów Uniwersyteckiej Kliniki Stomatologicznej w Krakowie. Badania CBCT zostały wykonane ze wskazań ogólnostomatologicznych u pacjentów leczonych na Oddziałach Ortodoncji, Chirurgii Stomatologicznej, Protetyki Stomatologicznej oraz Stomatologii Zachowawczej w latach 2019-2020. Wszystkie tomografie beneficial (7). The knowledge of the soft tissue thickness also facilitates selecting the appropriate mini-implant length and the length of its collar (8). According to Kyung et al., the implant should penetrate at least $6 \mathrm{~mm}$ into the bone (1).

There are various methods of assessing the mucosal thickness, such as: puncture of the palate with an endodontic instrument or periodontal probe after previous anaesthesia, or the use of an ultrasonograph (USG) (9-11). The ultrasound examination is minimally invasive and easy to perform; however, as reported by Müller et al., this examination is sensitive to the performance technique, and is less reliable, especially in thicker tissues (12).

At the beginning of the 21st century, computed tomography started to be used to assess the thickness of the mucosa covering the alveolar processes and the hard palate (13-16). CBCT (cone-beam computed tomography) was initially introduced for the assessment of the maxillofacial bone, and with time it has become an indispensable tool in the hands of dentists (17). Recently, a new method of cone-beam computed tomography of soft tissues has been presented. This new method allows an accurate assessment of the mucosal thickness, and values measured are similar to those obtained in other examination methods where physical measurements are used, such as an endodontic tool with a stopwatch or a periodontal probe $(9,11,16,17)$.

Previous studies have assessed the mucosa mainly in the lateral part of the palate and were intended to determine the best place to collect a connective tissue graft. The following study was designed because of the increasing popularity of systems based on mini-implants used for skeletal anchorage and placed in the area of the palatal suture.

\section{Aim}

The aim of the study was to assess the thickness of soft tissues covering the central part of the palate depending on the sex and age in terms of selecting the appropriate place for placement of mini-implants.

\section{Material and methods}

Research materials. Characteristics of the study group A retrospective analysis was performed on cone-beam computed tomography scans of 509 patients of the University Dental Clinic in Kraków. CBCT examinations were performed for general dental indications in patients treated at the departments of Orthodontics, Dental Surgery, Prosthodontics and Conservative Dentistry in 2019-2020. All computed tomography scans were performed at the Imaging Diagnostics Clinic of the University Dental Clinic in Kraków using the OP 3D Pro (KaVo, Germany) with average parameters: field of view $130 \times 150 \mathrm{~mm}$, average exposure time $8.5 \mathrm{~s}$, average scanning time $39 \mathrm{~s}$, average voxel size $380 \mu \mathrm{m}-5 \mathrm{~mA}$. 
komputerowe wykonano w Poradni Diagnostyki Obrazowej Uniwersyteckiej Kliniki Stomatologicznej w Krakowie za pomocą aparatu OP 3D Pro (KaVo, Niemcy) przy średnich parametrach: zakres 130 x $150 \mathrm{~mm}$, średni czas ekspozycji 8,5 s, średni czas naświetlania 39 s, średni rozmiar woksela $380 \mu \mathrm{m}-5 \mathrm{~mA}$.

Kryteria włączenia do badań stanowiły: wykorzystanie badań CBCT obejmujących obie kości szczęki u pacjentów Uniwersyteckiej Kliniki Stomatologicznej w Krakowie, wiek pacjentów powyżej 10 lat, negatywny wywiad w kierunku zabiegów chirurgicznych w zakresie błony śluzowej podniebienia, brak wad twarzoczaszki pacjenta, przynajmniej jednostronna obecność wszystkich zębów w szczęce, brak zmian patologicznych w obrębie kości lub błony śluzowej podniebienia, brak obecności zębów ze znacznymi zmianami morfologicznymi lub nasilonego stłoczenia zębów, nieużytkowanie przez pacjenta protez ruchomych i aparatów ortodontycznych.

Kryteria wyłączenia z badań stanowiły: badania CBCT na których język dotyka do podniebienia oraz zła jakość badania.

Na podstawie kryteriów włączających i wyłączających odrzucono 404 tomografie. Do badania zakwalifikowano skany 105 pacjentów w wieku 10-63 lat, gdzie średnia wieku wynosiła 28 lat, media wieku 27 lat, co pozwoliło na utworzenie dwóch grup badanych, grupa I - 55 kobiet i grupa II - 50 mężczyzn.

\section{Metodyka badań}

W badaniu analizowano obrazy tomografii komputerowej wiązki stożkowej, na których mierzono grubość błony śluzowej podniebienia w określonych 12 punktach.

Pomiary były dokonywane przez jednego badacza przy wykorzystaniu narzędzi programu InVivoDental (Anatomage, U.S., Santa Clara) na ekranie monitora diagnostycznego (RadiForce MX215). Ocenę rozpoczynano od odpowiedniego spozycjonowania obrazu względem trzech płaszczyzn:
The study inclusion criteria were as follows: use of CBCT scans involving both jaw bones in patients of the University Dental Clinic in Kraków, age of patients over 10 years, negative history of surgical procedures in the palatal mucosa, no craniofacial deformities, at least one-sided presence of all teeth in the maxilla, no pathological changes in the bone or palatal mucosa, no teeth with significant morphological changes or increased tooth crowding, no use of removable dentures or orthodontic appliances by the patient.

The study exclusion criteria were as follows: CBCT scans in which the tongue touched the palate and poor scan quality.

Based on the inclusion and exclusion criteria, 404 tomography scans were rejected. Scans of 105 patients aged 10-63 years were qualified for the study, the mean age was 28 , the median age was 27 years. Two study groups were created: group I - 55 women and group II - 50 men.

\section{Research methodology}

In the study, cone-beam computed tomography scans were analysed, and the thickness of the palatal mucosa was measured at 12 specific points.

Measurements were done by a single researcher using the InVivoDental programme (Anatomage, U.S., Santa Clara) and a medical diagnostic monitor (RadiForce MX215). The assessment began with appropriate positioning of the image in relation to three planes:

- the axial (horizontal) plane passing through the right and left Orbitale and right and left Porion points

- the frontal plane passing through the right and left Porion point, perpendicular to the axial plane

- the sagittal plane passing through the Nasion point, perpendicular to the axial and frontal planes.

The measurement points were located in relation to the distal margin of the incisive foramen (IF). In the first stage, the incisive foramen was located on the axial and sagittal sections. In the CBCT, points were marked on the axial crosssection at a distance of $3,6,10,18 \mathrm{~mm}$ from the distal margin

Tabela 1. Średnia grubość tkanek miękkich podniebienia w badanych punktach Table 1. Mean thickness of the palatal soft tissues in the measurement points

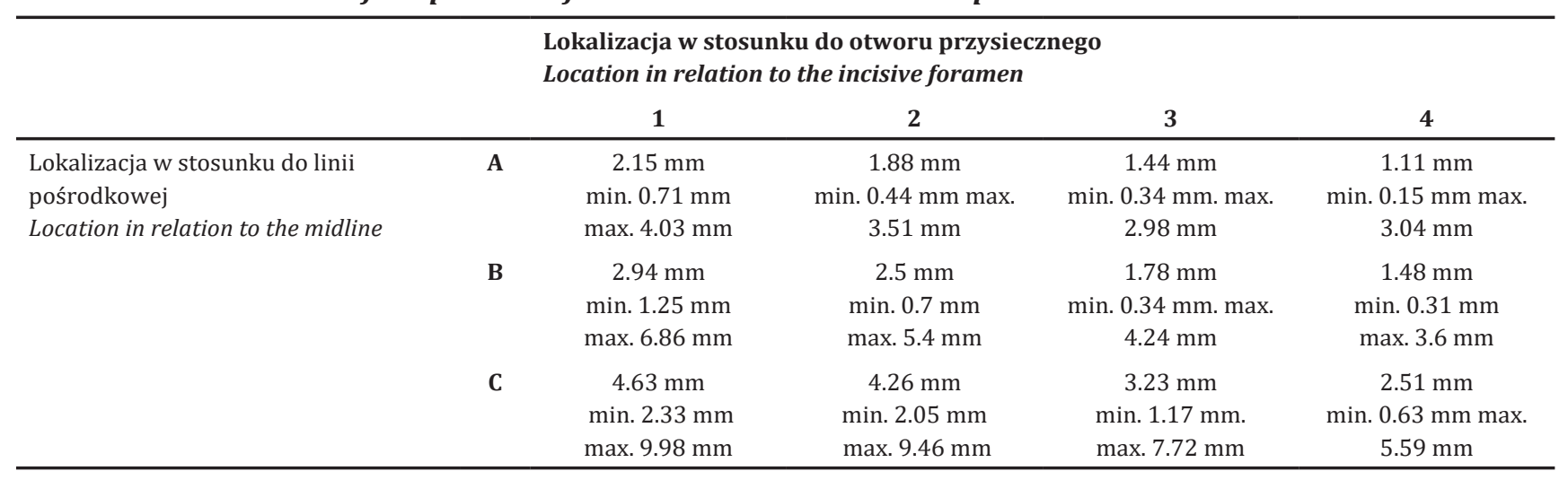


Assessment of the thickness of the palatal mucosa using cone-beam computed tomography

Tabela 2. Porównanie średnich pierwiastków sześciennych grubości błony śluzowej między płciami

Table 2. Comparison of mean cube roots of the mucosal thickness between sexes

\begin{tabular}{cccccc}
\hline & $\begin{array}{c}\text { Grupa I } \\
\text { Group I }\end{array}$ & $\begin{array}{c}\text { Grupa II } \\
\text { Group II }\end{array}$ & $\begin{array}{c}\text { test t- } \\
\text { wartość } \\
\text {-test } \\
\boldsymbol{p} \text {-value }\end{array}$ & $\begin{array}{c}\text { Przedział ufności } \\
\text { Confidence interval }\end{array}$ \\
\hline 1A & 1.253 & 1.294 & 0.1775 & -0.099 & 0.019 \\
1B & 1.395 & 1.439 & 0.1273 & -0.099 & 0.013 \\
1C & 1.645 & 1.657 & 0.7032 & -0.076 & 0.051 \\
2A & 1.203 & 1.222 & 0.5532 & -0.082 & 0.044 \\
2B & 1.310 & 1.372 & 0.05007 & $-1.24 \mathrm{e}-01$ & $0.00 \mathrm{e}-05$ \\
2C & 1.581 & 1.633 & 0.09361 & -0.113 & 0.009 \\
3A & 1.071 & 1.119 & 0.1679 & -0.116 & 0.020 \\
3B & 1.158 & 1.222 & 0.05109 & -0.128 & 0.000 \\
3C & 1.432 & 1.486 & 0.1154 & -0.121 & 0.013 \\
4A & 0.974 & 1.047 & 0.02528 & -0.136 & -0.009 \\
4B & 1.088 & 1.154 & 0.03074 & -0.126 & -0.006 \\
4C & 1.302 & 1.372 & 0.04177 & -0.139 & -0.003 \\
\hline
\end{tabular}

Tabela 3. Korelacja pierwiastka sześciennego grubości tkanek miękkich z wiekiem wg płci

Table 3. Correlation of the cube root of the soft tissue thickness with age depending on the sex

\begin{tabular}{|c|c|c|c|c|c|c|}
\hline & \multicolumn{2}{|l|}{$\begin{array}{l}\text { Grupa I } \\
\text { Group I }\end{array}$} & \multicolumn{2}{|c|}{$\begin{array}{l}\text { Grupa II } \\
\text { Group II }\end{array}$} & \multicolumn{2}{|c|}{$\begin{array}{c}\text { Grupa I+ II (tacznie) } \\
\text { Group I + II (total) }\end{array}$} \\
\hline & $\begin{array}{l}\text { ufności } \\
\text { Confidence } \\
\text { interval }\end{array}$ & $\begin{array}{l}\text { Wartość p } \\
P \text {-value }\end{array}$ & $\begin{array}{l}\text { Przedział ufności } \\
\text { Confidence interval }\end{array}$ & $\begin{array}{c}\text { Wartość p } \\
\text { P-value }\end{array}$ & $\begin{array}{l}\text { Przedział ufności } \\
\text { Confidence interval }\end{array}$ & $\begin{array}{c}\text { Wartość p } \\
P \text {-value }\end{array}$ \\
\hline $1 \mathrm{~A}$ & 0.079 & 0.5642 & -0.057 & 0.6935 & -0.000 & 0.9987 \\
\hline 1B & 0.133 & 0.3321 & 0.178 & 0.2162 & 0.131 & 0.1816 \\
\hline $1 \mathrm{C}$ & -0.000 & 0.9991 & 0.129 & 0.3722 & 0.059 & 0.5515 \\
\hline $2 \mathrm{~A}$ & 0.177 & 0.1958 & 0.003 & 0.9836 & 0.089 & 0.3661 \\
\hline $2 B$ & 0.161 & 0.2388 & 0.208 & 0.1475 & 0.152 & 0.1206 \\
\hline $2 \mathrm{C}$ & 0.185 & 0.1771 & -0.003 & 0.9851 & 0.056 & 0.5719 \\
\hline $3 \mathrm{~A}$ & 0.03 & 0.8294 & 0.121 & 0.4017 & 0.054 & 0.5836 \\
\hline 3B & 0.2949 & 0.02884 & 0.126 & 0.3827 & 0.173 & 0.07776 \\
\hline $3 C$ & 0.33 & 0.01392 & -0.012 & 0.9352 & 0.142 & 0.149 \\
\hline $4 \mathrm{~A}$ & 0.181 & 0.1866 & 0.070 & 0.6287 & 0.099 & 0.3149 \\
\hline $4 \mathrm{~B}$ & 0.171 & 0.2119 & 0.075 & 0.6066 & 0.091 & 0.3566 \\
\hline $4 \mathrm{C}$ & 0.168 & 0.2198 & 0.021 & 0.8833 & 0.07 & 0.4805 \\
\hline
\end{tabular}

- osiowej (horyzontalnej), przechodzącej przez punkty orbitale prawy i lewy oraz porion prawy i lewy

- czołowej, przechodzącej przez punkt porion prawy i lewy, prostopadłej do płaszczyzny osiowej

- strzałkowej, przechodzącej przez punkt nasion, prostopadłej do płaszczyzny osiowej i czołowej.

Punkty zlokalizowano w stosunku do dystalnej ściany otworu przysiecznego (OP). W pierwszym etapie of the incisive foramen (Fig. 1). Measurements of the mucosal thickness were made on the frontal section at the suture and 3 and $6 \mathrm{~mm}$ laterally to the suture. The following points were obtained: A1 - $3 \mathrm{~mm}$ behind the distal margin of the IF on the palatal suture, A2 - $6 \mathrm{~mm}$ behind the IF on the palatal suture, A3 - $10 \mathrm{~mm}$ behind the IF on the palatal suture, A4 - $18 \mathrm{~mm}$ behind the IF on the palatal suture, B1 - $3 \mathrm{~mm}$ behind the IF and $3 \mathrm{~mm}$ laterally from the palatal 


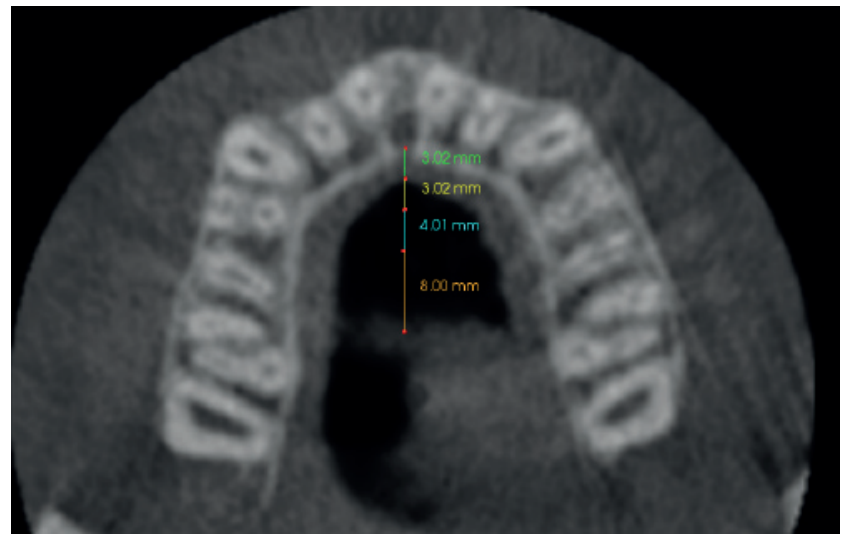

Rycina 1. Skan horyzontalny badania CBCT obrazujący schemat odległości punktów pomiarowych względem otworu przysiecznego.

Figure 1. Horizontal CBCT scan showing the distance between the measurement points and the incisive foramen.

lokalizowano otwór przysieczny na przekrojach osiowym i strzałkowym. W badaniu CBCT na przekroju osiowym wyznaczono punkty w odległości 3, 6, 10,18 mm od dystalnej ściany otworu przysiecznego (Ryc. 1). Pomiarów grubości błony śluzowej dokonywano na przekroju czołowym na szwie oraz 3 i $6 \mathrm{~mm}$ bocznie w stosunku do szwu, uzyskując punkty: A1 - $3 \mathrm{~mm}$ za dystalnym brzegiem OP na szwie podniebiennym, A2 - $6 \mathrm{~mm}$ za OP na szwie podniebiennym, A3 - $10 \mathrm{~mm}$ za OP na szwie podniebiennym, A4 - $18 \mathrm{~mm}$ za OP na szwie podniebiennym, B1 -punkt $3 \mathrm{~mm}$ za OP oraz 3 $\mathrm{mm}$ bocznie od szwu podniebiennego, B2 $-6 \mathrm{~mm}$ za OP oraz $3 \mathrm{~mm}$ bocznie od szwu podniebiennego, B3 $-10 \mathrm{~mm}$ za OP oraz $3 \mathrm{~mm}$ bocznie od szwu podniebiennego, B4 - $18 \mathrm{~mm}$ za OP oraz $3 \mathrm{~mm}$ bocznie od szwu podniebiennego, C1 punkt $3 \mathrm{~mm}$ za OP oraz $6 \mathrm{~mm}$ bocznie od szwu podniebiennego, C2 - $6 \mathrm{~mm}$ za OP oraz $6 \mathrm{~mm}$ bocznie od szwu podniebiennego, C3 $-10 \mathrm{~mm}$ za OP oraz $6 \mathrm{~mm}$ bocznie od szwu podniebiennego, C4 - $18 \mathrm{~mm}$ za OP oraz $6 \mathrm{~mm}$ bocznie od szwu podniebiennego (Ryc. 2, 3). Pomiary były wykonywane dwukrotnie (powtórzono je po dwóch tygodniach). Uzyskane wyniki liczono w milimetrach i zaokrąglano do drugiego miejsca po przecinku. W przypadku uzyskania dla danego punktu różnych wyników w dwóch pomiarach uśredniono ostateczny wynik.

\section{Analiza statystyczna}

Uzyskane dane poddano analizie statystycznej w celu oceny zależności grubości błony śluzowej w zależności od płci i wieku, średniej grubości błony śluzowej podniebienia oraz oceny zależności grubości śluzówki od lokalizacji w stosunku do otworu przysiecznego i w stosunku do linii pośrodkowej. Analizę statystyczną przeprowadzono z użyciem programu "R". Przy wykorzystaniu testu Shapiro-Wilka nie

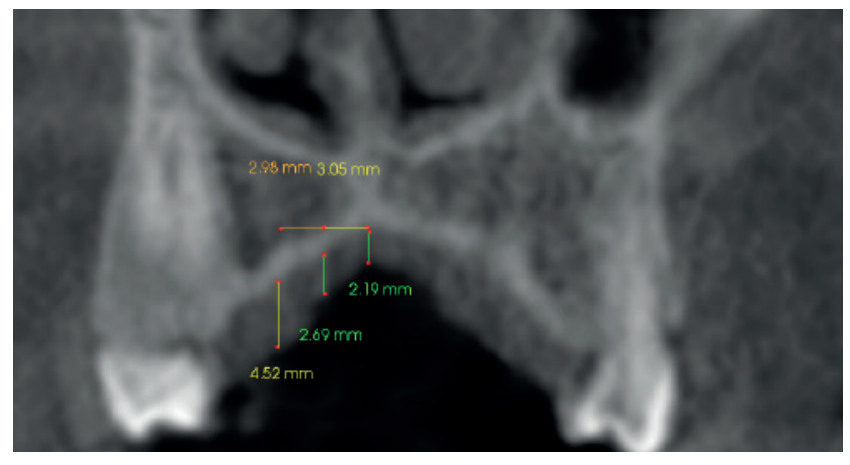

Rycina 2. Skan czołowy badania CBCT obrazujący schemat odległości punktów pomiarowych względem szwu podniebiennego.

Figure 2. Frontal CBCT scan showing the distance between the measurement points and the palatal suture.

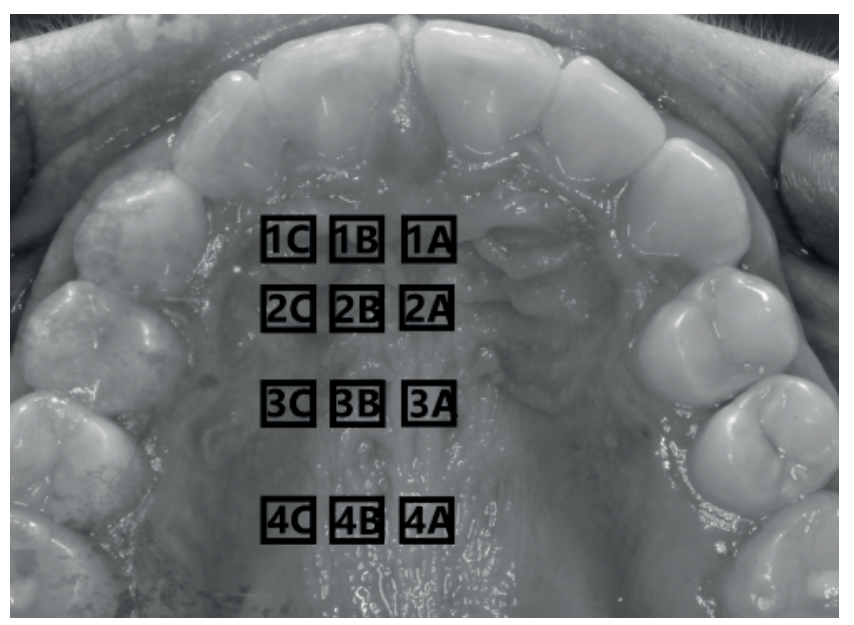

Rycina 3. Schemat punktów pomiarowych.

Figure 3. Diagram of the measurement points.

suture, B2 - $6 \mathrm{~mm}$ behind the IF and $3 \mathrm{~mm}$ laterally from the palatal suture, B3 $-10 \mathrm{~mm}$ behind the IF and $3 \mathrm{~mm}$ laterally from the palatal suture, B4 - $18 \mathrm{~mm}$ behind the IF and $3 \mathrm{~mm}$ laterally from the palatal suture, $\mathrm{C} 1-3 \mathrm{~mm}$ behind the IF and $6 \mathrm{~mm}$ laterally from the palatal suture, $\mathrm{C} 2-6 \mathrm{~mm}$ behind the IF and $6 \mathrm{~mm}$ laterally from the palatal suture, C3 - 10 $\mathrm{mm}$ behind the IF and $6 \mathrm{~mm}$ laterally from the palatal suture, C4 - $18 \mathrm{~mm}$ behind the IF and $6 \mathrm{~mm}$ laterally from the palatal suture (Fig. 2, 3). Measurements were performed twice (for the first time and then repeated after two weeks). Obtained results were recorded in millimetres and rounded to two decimal places. When different results for a specific point were obtained in two measurements, the final result was averaged. 
Assessment of the thickness of the palatal mucosa using cone-beam computed tomography

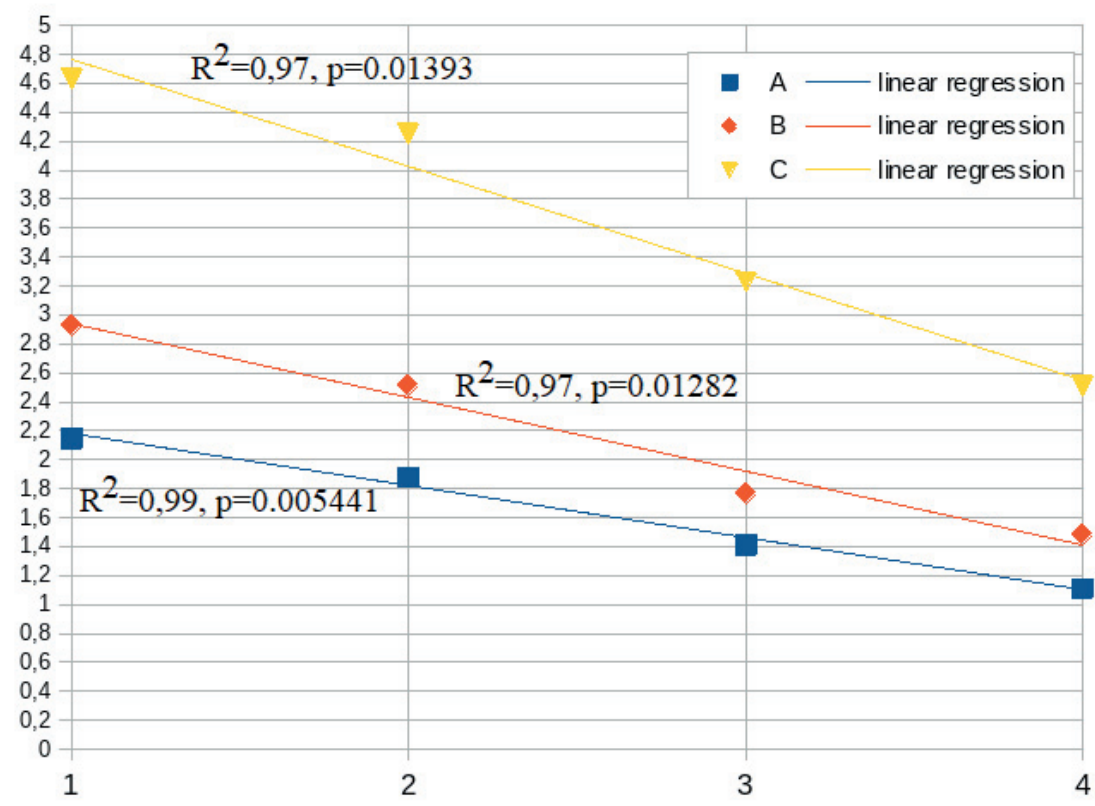

Rycina 4. Korelacja średniej grubości tkanek miękkich z odległością od otworu przysiecznego w pozycjach A, B, C. Figure 4. Correlation of the mean soft tissue thickness with the distance from the incisive foramen in positions $A, B, C$.

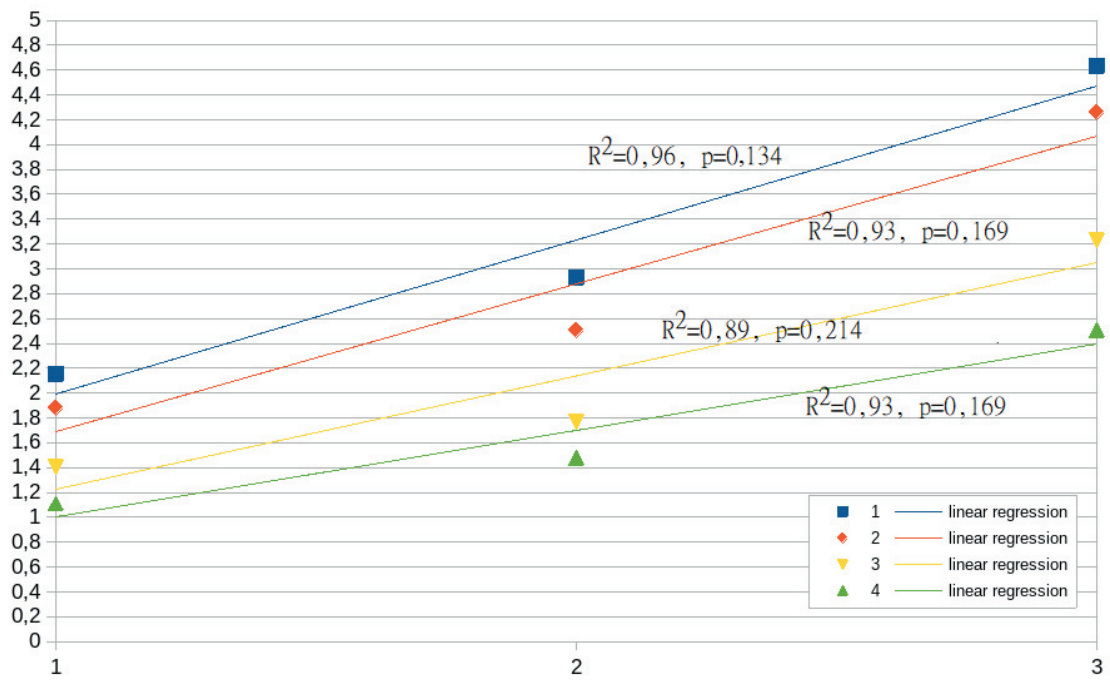

Rycina 5. Korelacja średniej grubości tkanek miękkich z odległością od osi pośrodkowej w pozycjach 1, 2, 3, 4. Figure 5. Correlation of the mean soft tissue thickness with the distance from the midline in positions $A, B, C$.

zaobserwowano rozkładu normalnego danych, dlatego dane zostały znormalizowane przez potęgowanie $(19,20)$.

Badanie zostało zaakceptowane przez Komisję Bioetyczną Uniwersytetu Jagiellońskiego w Krakowie (Nr 1072.6120.108.2020, data 28.05.2020 r.).

\section{Wyniki}

Wartości średnie, minimalne i maksymalne pomiarów zebrano w tabeli 1. Wśród ocenianych punktów

\section{Statistical analysis}

Obtained data were statistically analysed in order to evaluate the relationship of the mucosal thickness by sex and age, the average thickness of the palatal mucosa, and also to assess the relationship between the mucosal thickness and the location in relation to the incisive foramen and the midline. Statistical analysis was performed using the "R" programme. Using the Shapiro-Wilk test normal distribution of the data was not observed; therefore the data were normalised by exponentiation $(19,20)$. 
pomiarowych najcieńsza błona śluzowa znajdowała się na szwie podniebiennym, $18 \mathrm{~mm}$ za tylnym brzegiem otworu przysiecznego (punkt A4). Grubość tkanek miękkich zmniejsza się wraz ze wzrostem odległości od otworu przysiecznego $(\mathrm{A} 4<\mathrm{A} 3<\mathrm{A} 2<\mathrm{A} 1$ ) oraz zwiększa się, im dalej od linii szwu podniebiennego $(\mathrm{A} 1<\mathrm{B} 1<\mathrm{C} 1$, A2 $<$ B2 $<$ C2, A3 $<$ B3 $<$ C3, A4 < B4 < C4).

Ocena grubości błony śluzowej podniebienia w zależności od płci wykazała, że grubość tkanek miękkich jest istotnie statystycznie większa u mężczyzn w punktach 4A, 4B oraz 4C, czyli w całym obszarze znajdującym się $18 \mathrm{~mm}$ za dystalnym brzegiem otworu przysiecznego. $\mathrm{W}$ pozostałych mierzonych punktach nie stwierdzono pomiędzy płciami istotnych statystycznie różnic w grubości tkanek miękkich (Tab. 2).

W badaniu stwierdzono, że istnieje zależność statystyczna pomiędzy odległością od otworu przysiecznego a grubością tkanek miękkich. Wykazano również, że ma ona charakter liniowy (Ryc. 4). Im dalej ku tyłowi od otworu przysiecznego, tym warstwa tkanek miękkich staje się cieńsza.

W analizie korelacji pomiędzy odległością od linii pośrodkowej a grubością tkanek miękkich uzyskano wysokie współczynniki determinacji (Ryc. 5). Jednak wyniki analizy nie pozwalają wnioskować o istnieniu takiej zależności.

W badaniu stwierdzono, że dla kobiet w punktach pomiarowych 3B oraz 3C wraz $\mathrm{z}$ wiekiem istotnie statystycznie zwiększa się grubości tkanek miękkich (Tab. 3). Dla kobiet w punkcie 3B w grupie wiekowej 10-19 lat średnia grubość tkanek miękkich wynosi 1,32 mm, w grupie wiekowej 20-29 lat wynosi 1,61 mm, w grupie wiekowej 30-39 lat wynosi $1,71 \mathrm{~mm}$, a w grupie wiekowej 40-63 lata wynosi $1,92 \mathrm{~mm}$. Dla kobiet w punkcie 3C w grupie wiekowej 10-19 lat średnia grubość tkanek miękkich wynosi 2,55 mm, w grupie wiekowej 20-29 lat wynosi 3,04 mm, w grupie wiekowej 30-39 lat wynosi 3,03 mm, a w grupie wiekowej 40-63 lata wynosi 3,73 mm. Dla mężczyzn oraz kobiet w pozostałych punktach pomiarowych (poza punktami 3B oraz 3C) nie występują istotne statystycznie zmiany w grubości tkanek miękkich w wieku pomiędzy 10 a 63 rokiem życia.

\section{Dyskusja}

Tkanki miękkie podniebienia są coraz częściej obszarem zainteresowania chirurgów, implantologów, periodontologów (przeszczepy łącznotkankowe, nabłonkowo-łącznotkankowe), jak również ortodontów (zakotwienie szkieletowe). Aby skrócić czas i zwiększyć przewidywalność zabiegów w tej okolicy istnieje potrzeba dokładnej analizy grubości tkanek miękkich podczas planowania zabiegów. Dotychczas wśród klinicystów standardem postępowania było nakłucie podniebienia sondą periodontologiczną lub narzędziem endodontycznym w znieczuleniu miejscowym. Zazwyczaj robiono to bezpośrednio przed zabiegiem, co utrudniało dokładne zaplanowanie zabiegu z wyprzedzeniem. Większość lekarzy nie wykonuje punkcji diagnostycznej na wcześniejszych wizytach, aby
The study was approved by the Bioethics Committee of the Jagiellonian University in Kraków (No. 1072.6120.108.2020, date 28/05/2020).

\section{Results}

Table 1 shows the mean, minimum and maximum values of the measurements. Among the assessed measurement points, the thinnest mucosa was located at the palatal suture, 18 $\mathrm{mm}$ behind the posterior margin of the incisive foramen (point A4). The soft tissue thickness decreases with an increasing distance from the incisive foramen $(\mathrm{A} 4<\mathrm{A} 3<\mathrm{A} 2$ $<\mathrm{A} 1)$ and increases the further from the palatal suture line $(\mathrm{A} 1<\mathrm{B} 1<\mathrm{C} 1, \mathrm{~A} 2<\mathrm{B} 2<\mathrm{C} 2, \mathrm{~A} 3<\mathrm{B} 3<\mathrm{C} 3, \mathrm{~A} 4<\mathrm{B} 4<\mathrm{C} 4)$.

The assessment of the thickness of the palatal mucosa depending on the sex showed that the soft tissue thickness was statistically significantly greater in men at points $4 \mathrm{~A}$, $4 \mathrm{~B}$ and $4 \mathrm{C}$, i.e. in the whole area $18 \mathrm{~mm}$ behind the distal margin of the incisive foramen. Regarding other measurement points, there were no statistically significant differences in the soft tissue thickness (Tab. 2).

The study demonstrated that there was a statistical relationship between the distance from the incisive foramen and the soft tissue thickness. It was also shown that this relationship was linear (Fig. 4). The further back from the incisive foramen, the thinner the soft tissues are.

When a comparison of the distance from the midline and the soft tissue thickness was performed, high coefficients of determination were obtained (Fig. 5). However, the analysis results do not allow us to conclude that there is a statistical relationship.

The study found that at measurement points 3B and 3C, the soft tissue thickness increased statistically with age in women (Table 3). In women, in point 3B in the 10-19 age group, the average soft tissue thickness is $1.32 \mathrm{~mm}$, in the 20-29 age group it is $1.61 \mathrm{~mm}$, in the $30-39$ age group it is $1.71 \mathrm{~mm}$, and in the 40-63 age group it is $1.92 \mathrm{~mm}$. In women, in point $3 \mathrm{C}$ in the 10 -19 age group, the average soft tissue thickness is $2.55 \mathrm{~mm}$, in the $20-29$ age group it is $3.04 \mathrm{~mm}$, in the 30-39 age group it is $3.03 \mathrm{~mm}$, and in the 40-63 age group it is $3.73 \mathrm{~mm}$. In both men and women, in the remaining measurement points (except for points 3B and 3C), between the age of 10 and 63 years there are no statistically significant changes in the soft tissue thickness.

\section{Discussion}

Palatal soft tissues are more and more often the area of interest for surgeons, implantologists, periodontists (connective tissue grafts, epithelial-connective tissue grafts), as well as orthodontists (skeletal anchorage). In order to reduce time and increase the predictability of treatments in this area, there is a need for a careful analysis of the soft tissue thickness when planning the procedures. So far, the 
Assessment of the thickness of the palatal mucosa using cone-beam computed tomography

zminimalizować konieczność dodatkowych znieczuleń i dyskomfort pacjenta. Istnieje więc potrzeba nieinwazyjnej diagnostyki tkanek miękkich podniebienia - część autorów rekomenduje wykorzystanie do tego celu badania ultrasonograficznego. Jednak ta metoda jest wrażliwa na technikę wykonania i w przypadku tkanek grubszych daje wyniki obarczone błędem (12). Dodatkowo ultrasonograf nie jest powszechnie dostępnym sprzętem w gabinetach stomatologicznych, co znacznie obniża możliwości praktycznego i powszechnego zastosowania tej metody. Ostatnio pojawiła się koncepcja wykorzystania do tego celu tomografii wiązki stożkowej.

Tomografia wiązki stożkowej, inaczej nazywana tomografią wolumetryczną, jest przez większość lekarzy uważana za badanie dedykowane do oceny zębów oraz kości, ponieważ pozwala na dokładną analizę tkanek twardych. W przypadku tkanek miękkich podniebienia w badaniu CBCT nie ma możliwości rozróżnienia poszczególnych struktur od siebie (takich jak nabłonek, tkanka łączna, tkanka tłuszczowa, okostna) i wszystkie tkanki miękkie wyglądają jak jednolita masa. Tomografia wolumetryczna pozwala jednak na ocenę zarysu tkanek miękkich, a co za tym idzie - ocenę ich wielkości i objętości.

Ocena grubości tkanek miękkich podniebienia na podstawie tomografii komputerowej jest stosunkowo nową metodą. Według wiedzy autorów dotychczas zostało opublikowane jedynie 6 artykułów podejmujących tę tematykę $(13,15,16$, 21-23). Dwa z nich wykorzystują do pomiarów konwencjonalne tomografy wiązki spiralnej $(13,23)$. Ueno i wsp. wykazali wysoką korelację pomiędzy wynikami pomiarów grubości tkanek miękkich przy użyciu spiralnej tomografii komputerowej oraz pomiarów fizycznych (z wyjątkiem bardzo cienkich tkanek) (23). Pozostałe 4 artykuły dotyczą analizy grubości tkanek na podstawie tomografii wolumetrycznej w różnych miejscach podniebienia $(15,16,21,22)$.

Standardowo wykonana tomografia wiązki stożkowej może nie być wystarczająca do oceny grubości tkanek miękkich podniebienia, ponieważ podczas wykonywania badania język pacjenta nieraz dotyka do podniebienia i granica pomiędzy błoną śluzową języka a podniebienia nie może być wówczas ustalona. Ponieważ niniejsze badanie jest badaniem retrospektywnym, autorzy odrzucili wszystkie tomografie, na których powyższy warunek nie był spełniony i analizowali jedynie tomografie, na których język nie stykał się z podniebieniem. Barriviera i wsp. zalecają na czas wykonywania badania CBCT założenie szpatułki pomiędzy pierwsze zęby trzonowe szczęki i żuchwy. Tak trzymana szpatułka nie pozwala językowi podczas badania stykać się z podniebieniem i umożliwia późniejszą ocenę jego grubości (15).

W dotychczas przeprowadzonych badaniach wykorzystujących CBCT liczba przeanalizowanych tomografii wynosiła 31, 36 oraz $44(15,21,22)$. W niniejszym badaniu autorzy zakwalifikowali i przeanalizowali 105 tomografii. standard of care among clinicians has been to puncture the palate with a periodontal probe or an endodontic tool under local anaesthesia. Usually, it was done immediately before the procedure, which made it difficult to plan accurately in advance. Most doctors do not perform diagnostic puncture at earlier visits to minimise the need for additional anaesthesia and the patient's discomfort. Consequently, there is a need for non-invasive diagnostic methods of the palatal soft tissues. Some authors recommend the use of an ultrasound examination for this purpose. However, this method is operator-sensitive, and in case of thicker tissues, it does not give precise results (12). In addition, ultrasonographs are not commonly available in dental offices, and it significantly reduces the possibility of a practical and common use of this method. Recently, the concept of using cone-beam computed tomography for the evaluation of the palatal soft tissues has been proposed.

Cone-beam computed tomography, otherwise known as volumetric tomography, is considered by most doctors to be a diagnostic method dedicated to assessing teeth and bones, because it allows for a thorough analysis of the hard tissues. However, in the case of the palatal soft tissues, CBCT examination does not distinguish individual structures from each other (such as epithelium, connective tissue, adipose tissue, periosteum), and all soft tissues appear as a uniform mass. However, volumetric tomography allows assessing the outline of the soft tissues, and thus their size and volume.

The assessment of the thickness of the palatal soft tissues using computed tomography is a relatively new method. To the authors' knowledge, so far only 6 articles covering this subject have been published $(13,15,16$, 21-23). Two of them use conventional spiral beam tomographs for measurements $(13,23)$. Ueno et al. showed a high correlation between the results of soft tissue thickness measurements using spiral computed tomography and physical measurements (except for very thin tissues) (23). The remaining 4 articles concern the analysis of the tissue thickness based on volumetric tomography in various areas of the palate $(15,16,21,22)$.

Standard cone-beam computed tomography may not be sufficient to assess the thickness of palatal soft tissues, because the patient's tongue sometimes touches the palate during the examination, and the border between the mucosa of the tongue and the palate cannot be determined. This study is retrospective, and therefore the authors rejected all tomography scans in which the above condition was not met and analysed only those in which the tongue was not in contact with the palate. Barriviera et al. recommend placing a spatula between the first molars of the maxilla and mandible during a CBCT examination. When the spatula is in this position, it does not allow the tongue to come into contact with the palate, and consequently it is possible to assess the thickness of the palatal soft tissues (15). 
Dobór mierzonych punktów podyktowany jest tym, czy badacze analizują podniebienie pod kątem pobierania przeszczepów łącznotkankowych, czy pod kątem zakładania miniimplantów ortodontycznych. Barriviera i wsp., Song i wsp. oraz Ueno i wsp., Ogawa i wps. jako punkt odniesienia wybrali brzeg dziąsła lub połączenie szkliwno-cementowe podniebiennej strony kłów, przedtrzonowców oraz trzonowców $(13,15$, 16, 22). Barriviera i wsp. przeprowadzał pomiary 2, 5, 8, 12 mm od brzegu dziąsła (15). Song i wsp. również odnosili się do brzegu dziąsła, ale mierzyli grubość tkanek w odległości 3, 6, 9, $12 \mathrm{~mm}$ od niego (13). Ueno i wsp. natomiast przeprowadzali pomiary w $3 \mathrm{~mm}$ odstępach od połączenia szkliwno-cementowego zębów, aż do linii pośrodkowej podniebienia (22). Zarówno wybór brzegu dziąsła jak i połączenia szkliwno-cementowego jako punktu odniesienia wydają się być obarczone błędami ze względu na powszechnie występujące w populacji braki zębów, wady zębowe, rotacje zębów, recesje lub inne problemy periodontologiczne. Marquezan i wsp. jako punkt odniesienia wybrali tylną ścianę otworu przysiecznego i wyznaczyli punkty $4,8,16$ oraz $24 \mathrm{~mm}$ dystalnie od niego oraz na linii pośrodkowej i 3, $6 \mathrm{~mm}$ dobocznie od niej (21). W niniejszym badaniu pomiary przeprowadzano w odległości 3, 6, $10,18 \mathrm{~mm}$ od dystalnej ściany otworu przysiecznego oraz w linii pośrodkowej i 3, 6 mm dobocznie. Punkty wybrane przez autorów są zlokalizowane bardziej mezjalnie niż w badaniu Marquezan, ze względu na częstsze pozycjonowanie miniimplantów w przedniej części podniebienia.

W niniejszym badaniu wykazano, że tkanki miękkie podniebienia są najgrubsze w jego przedniej części i stają się coraz cieńsze w kierunku dystalnym. Te informacje są spójne z wcześniejszymi doniesieniami Marquezan (21), która wykazała również, że tkanki miękkie w linii pośrodkowej podniebienia są cieńsze niż bocznie od niej. Surowe dane liczbowe w niniejszym badaniu również wskazują na taką zależność, jednak analiza statystyczna jej nie potwierdziła.

W badaniach własnych stwierdzono, że tkanki miękkie są grubsze u mężczyzn niż u kobiet w obszarze znajdującym się $18 \mathrm{~mm}$ za dystalnym brzegiem otworu przysiecznego. W pozostałych mierzonych punktach nie stwierdzono istotnych statystycznie różnic w grubości śluzówki pomiędzy płciami. Barriviera i wsp., Studer i wsp. oraz Waraaswapati i wsp. twierdzą, że nie ma różnic w grubości tkanek miękkich podniebienia pomiędzy mężczyznami i kobietami (9, 11, 15). Natomiast Song i wsp., Muller i wsp., Ostlund oraz Ogawa i wps. donoszą, że tkanki miękkie podniebienia są grubsze u mężczyzn niż u kobiet $(16,24)$.

W niniejszym badaniu stwierdzono, że u kobiet w punktach pomiarowych B3 (10 $\mathrm{mm}$ za OP oraz $3 \mathrm{~mm}$ bocznie od szwu podniebiennego) oraz C3 (10 $\mathrm{mm}$ za OP oraz $6 \mathrm{~mm}$ bocznie od szwu podniebiennego) z wiekiem istotnie statystycznie zwiększa się grubości tkanek miękkich. Barriviera i wsp. donoszą, że u osób starszych (powyżej 40 r.ż) tkanki miękkie podniebienia są grubsze niż u osób młodszych (poniżej 40 r.ż.) (15). Song i wsp. donoszą, że u osób w grupie
In the studies conducted so far and using CBCT, the number of analysed tomography scans was 31,36 and $44(15,21,22)$. In this study, the authors qualified and analysed 105 tomography scans.

The selection of measured points depends on whether researchers analyse the palate in terms of its usefulness for collecting connective tissue grafts or in terms of placing orthodontic mini-implants. Barriviera et al., Song et al. and Ueno et al. chose a gingival margin or the cemento-enamel junction of the palatal side of canines, premolars and molars as reference points $(13,15,16,22)$. Barriviera et al. performed measurements at the distance of 2, 5, 8, $12 \mathrm{~mm}$ from the gingival margin (15). Song et al. also referred to the gingival margin, but measured the tissue thickness at the distance of 3, 6, 9, $12 \mathrm{~mm}$ from it (13). On the other hand, Ueno et al. performed measurements at 3$\urcorner-\mathrm{mm}$ intervals from the cemento-enamel junction of the teeth up to the palate midline (22). The selection of the gingival margin and the cemento-enamel junction as reference points seems to be flawed due to the fact that tooth deficiencies, dental defects, tooth rotations, recessions or other periodontal problems are common in the population. Marquezan et al. chose the posterior wall of the incisive foramen as a point of reference and estimated points 4, 8, 16 and $24 \mathrm{~mm}$ distally from it and on the midline, and 3, $6 \mathrm{~mm}$ laterally from it (21). In the current study, measurements were done at 3, 6, 10, $18 \mathrm{~mm}$ from the distal margin of the incisive foramen and at the midline, and 3, $6 \mathrm{~mm}$ laterally from it. Points selected by the authors are located more mesially than in the Marquezan study due to more frequent positioning of mini-implants in the anterior part of the palate.

This study has shown that the palatal soft tissues are the thickest at the front of the palate and become thinner distally. This information is consistent with previous reports by Marquezan (21) that also showed that the soft tissues in the palate midline were thinner than laterally. Raw figures in this study also indicate such a relationship, but a statistical analysis does not confirm it.

The author's research found that soft tissues were thicker in men than in women in the area $18 \mathrm{~mm}$ behind the distal margin of the incisive foramen. In other measured points, no statistically significant differences in the mucosal thickness between the sexes were found. Barriviera et al., Studer et al. and Waraaswapati et al. argue that there are no differences in the thickness of the palatal soft tissues between men and women $(9,11,15)$. On the other hand, Song et al., Muller et al., Ostlund and Ogawa et al. report that the palatal soft tissues are thicker in men than in women $(16,24)$.

The present study found that in women at B3 $(10 \mathrm{~mm}$ behind the IF and $3 \mathrm{~mm}$ laterally from the palatal suture) and $\mathrm{C} 3(10 \mathrm{~mm}$ behind the IF and $6 \mathrm{~mm}$ lateral from the palatal suture) measurement points the soft tissue thickness increased statistically with age. Barriviera et al. report that in older people (over 40 years of age), the palatal soft 
Assessment of the thickness of the palatal mucosa using cone-beam computed tomography

wiekowej 41--0 lat oraz 51-60 lat tkanki miękkie podniebienia są statystycznie grubsze niż u osób w grupie wiekowej 21-30 lat (13). Z badań Ogawy i wsp. wynika, że u mężczyzn w pewnych lokalizacjach na podniebieniu występuje grubsza błona śluzowa niż u kobiet, natomiast Marquezan i wsp. twierdzą, że nie ma korelacji pomiędzy wiekiem a grubością tkanek miękkich $(16,21)$.

W dyskusji autorzy odnoszą się zarówno do badań, w których opierano się na konwencjonalnej tomografii spiralnej, jak i badań dotyczących tomografii wiązki stożkowej $(13,15$, 21-23). Jest to spowodowane niewielką liczbą artykułów dotyczących tematu zainteresowania. Należy jednak zaznaczyć, że tomografy spiralne wykorzystują znacznie większą dawkę promieniowania, a w związku z tym są mniej obojętne dla pacjentów. Dodatkowo gabinety stomatologiczne nie dysponują konwencjonalnymi tomografami spiralnymi, co powoduje, że ich kliniczne zastosowanie do oceny grubości tkanek miękkich podniebienia również w przewidywalnej przyszłości będzie znikome. Ultrasonografia jest nieinwazyjna, ale wyniki pomiarów są obarczone błędem, a sprzęt jest mało dostępny. Metody fizyczne (nakłucie sondą lub narzędziem endodontycznym) są proste, ale inwazyjne i wiążą się z dyskomfortem dla pacjenta. Natomiast tomografia wiązki stożkowej (CBCT) wydaje się być narzędziem łączącym zalety wszystkich dotychczas wykorzystywanych metod.

Znajomość grubości tkanek miękkich ma znaczenie dla ortodontów przed założeniem miniimplantów na podniebieniu. Pozwala na dobór implantu o odpowiedniej długości, jak również na dobór implantu o odpowiednim kołnierzu przechodzącym przez tkanki miękkie.

Ze względu na ograniczenia związane między innymi ze zróżnicowaną budową anatomiczną zarówno tkanek twardych jak i miękkich podniebienia, a także anomaliami ułożenia zębów wynikającymi ze stłoczeń czy braków zębowych, autorom dotychczasowych prac naukowych nie udało się ustalić spójnej metodyki pomiaru grubości tkanek miękkich podniebienia. Określenie idealnego miejsca i sposobu pomiaru grubości błony śluzowej podniebienia wymagają dalszych badań i mogą być tematem kolejnej pracy naukowej.

\section{Wnioski}

W badaniu stwierdzono, że grubość tkanek miękkich pokrywających centralną część podniebienia różni się w zależności od płci, wieku oraz lokalizacji na podniebieniu. Grubość tkanek miękkich jest większa u mężczyzn niż u kobiet w obszarze podniebienia znajdującym się $18 \mathrm{~mm}$ za dystalnym brzegiem otworu przysiecznego. W pozostałych mierzonych punktach znajdujących się bliżej otworu przysiecznego nie stwierdzono istotnych statystycznie różnic w grubości śluzówki pomiędzy płciami. Im dalej ku tyłowi od otworu przysiecznego oraz im bliżej linii pośrodkowej podniebienia, tym tkanki miękkie są cieńsze i tworzą dogodniejsze warunki do umieszczenia miniimplantów. tissues are thicker than in younger people (under 40 years of age) (15). Song et al. report that in people who are 41-50 years old and 51-60 years old, the palatal soft tissues are statistically thicker than in people who are 21-30 years old (13). Studies by Ogawa et al. show that men have a thicker mucosa in specific locations of the palate than women, while Marquezan et al. claim that there is no correlation between the age and the soft tissue thickness $(16,21)$.

In the discussion, the authors refer both to studies based on conventional spiral tomography and studies on conebeam tomography $(13,15,21-23)$. It is related to a small number of articles on the subject of interest. However, it should be noted that spiral tomographs use much higher doses of radiation and are therefore less indifferent to patients. In addition, dental offices do not have conventional spiral tomographs, and it means that their clinical application to assess the thickness of the palatal soft tissues is and will be negligible in the foreseeable future. Ultrasonography is non-invasive, but the measurement results are flawed, and the equipment is scarce. Physical methods (puncture with a probe or endo tool) are simple but invasive and cause discomfort for the patient. On the other hand, cone-beam computed tomography (CBCT) seems to be a tool that combines the advantages of all methods mentioned above.

Before placing mini-implants on the palate, it is essential for orthodontists to know the thickness of the covering soft tissues. It allows selecting an appropriate implant length, as well as selecting an implant with an appropriate transmucosal neck passing through the soft tissues.

Due to limitations related to the varied anatomical structure of both the hard and soft palate, different tooth positions as a result of crowding or missing teeth, the authors of previous studies have not been able to establish a consistent methodology for measuring the thickness of the palatal soft tissues. Determining the ideal place and method of measuring the mucosal thickness requires further research and may be the subject of another study.

\section{Conclusions}

The study stated that the thickness of the soft tissues covering the central part of the palate varied according to sex, age and location on the palate. The soft tissue thickness in men is greater than in women in the area of the palate 18 $\mathrm{mm}$ behind the distal margin of the incisive foramen. In other measured points located closer to the incisive foramen, no statistically significant differences in the mucosal thickness between the sexes were found. The further back from the incisive foramen and the closer to the palate midline, the thinner the soft tissues and the more convenient conditions for placing mini-implants. 


\section{Piśmiennictwo / References}

1. Kyung H, Park HS, Bae S, Sung Jhm Kim I. Development of Orthodontic Micro-Implants for Intraoral Anchorage. J Clin Orthod 2003; 37: 321-8.

2. Kang S, Lee SJ, Ahn SJ, Heo MS, Kim TW. Bone thickness of the palate for orthodontic mini-implant anchorage in adults. Am J Orthod Dentofacial Orthop 2007; 131: 74-81.

3. Moon SH, Park SH, Lim WH, Chun YS. Palatal bone density in adult subjects: Implications for mini-implant placement. Angle Orthod 2010; 80: 137-44.

4. King KS, Lam EW, Faulkner MG, Heo G, Major PW. Vertical bone volume in the paramedian palate of adolescents: A computed tomography study. Am J Orthod Dentofacial Orthop 2007; 132: 783-8.

5. Arcuri C, Muzzi F, Santini F, Barlattani A, Giancotti A. Five Years of Experience Using Palatal Mini-Implants for Orthodontic Anchorage. J Oral Maxillofac Surg 2007; 65: 2492-7.

6. Lee JS, Doo HK, Park YC, Kyung SH, Kim TK. The efficient use of midpalatal miniscrew implants. Angle Orthod 2004; 74: 711-4.

7. Kim HJ, Yun HS, Park H Do, Kim DH, Park YC. Soft-tissue and cortical-bone thickness at orthodontic implant sites. Am J Orthod Dentofac Orthop 2006; 130: 177-82.

8. Melsen B. Mini-Implants: Where Are We? J Clin Orthod 2005; 39: 539-47.

9. Wara-aswapati N, Pitiphat W, Chandrapho N, Rattanayatikul C, Karimbux N. Thickness of Palatal Masticatory Mucosa Associated With Age. J Periodontol 2001; 72: 1407-12.

10. Schaller N, Eger T. Ultrasonic determination of thickness of masticatory mucosa. Pathology 1999: 248-53.

11. Studer SP, Allen EP, Rees TC, Kouba A. The Thickness of Masticatory Mucosa in the Human Hard Palate and Tuberosity as Potential Donor Sites for Ridge Augmentation Procedures. J Periodontol 1997; 68: 145-51.

12. Müller HP, Schaller N, Eger T. Ultrasonic determination of thickness of masticatory mucosa A methodologic study. Oral Surg Oral Med Oral Pathol Oral Radiol Endod 1999; 88: 248-53.

13. Song JE, Um YJ, Kim CS, Choi SH, Cho KS, Kim CK, Chai JK, Jung UW. Thickness of Posterior Palatal Masticatory Mucosa: The Use of Computerized Tomography. J Periodontol 2008; 79: 406-12.
14. Bernhart T, Vollgruber A, Gahleitner A, Dörtbudak O, Haas R. Alternative to the median region of the palate for placement of an orthodontic implant. Clin Oral Implants Res 2000; 11: 595-601.

15. Barriviera M, Duarte WR, Januário AL, Faber J, Bezerra ACB. A new method to assess and measure palatal masticatory mucosa by cone-beam computerized tomography. J Clin Periodontol 2009; 36: 564-8.

16. Ogawa M, Katagiri S, Koyanagi T, Maekawa S, Shiba T, Ohsugi Y, Takeuchi Y, Ikawa T, Takeuchi S, Sekiuchi T, Arai Y, Kazama R, Wakabayashi N, Izumi Y, Iwata T. Accuracy of cone beam computed tomography in evaluation of palatal mucosa thickness. J Clin Periodontol 2020; 47: 479-88.

17. Practice D, Scarfe WC, Farman AG. Clinical Applications of ConeBeam Computed. J Can Dent Assoc 2006; 72: 75-80.

18. Januário AL, Barriviera M, Duarte WR. Soft tissue cone-beam computed tomography: A novel method for the measurement of gingival tissue and the dimensions of the dentogingival unit. J Esthet Restor Dent 2008; 20: 366-73.

19. Pohlert T. The Pairwise Multiple Comparison of Mean Ranks Package (PMCMR). Dostępny w Internecie: https://cran.r-project.org/web/packages/PMCMR/PMCMR.pdf

20. Foundation RCTR. R: A Language and Environment for Statistical Computing [Internet]. 2013: 2: Dostępny w Internecie: http:// www.gnu.org/copyleft/gpl.html

21. Marquezan M, Nojima LI, de Freitas AOA, Baratieri C, Alves Júnior M, Nojima M da CG, Araujo MT. Tomographic mapping of the hard palate and overlying mucosa. Braz Oral Res 2012; 26: 36-42.

22. Ueno D, Sekiguchi R, Morita M, Jayawardena A, Shinpo S, Sato J, Kobayashi K. Palatal mucosal measurements in a japanese population using cone-beam computed tomography. J Esthet Restor Dent 2014; 26: 48-58.

23. Ueno D, Sato J, Igarashi C, Ikeda S, Morita M, Shimoda S, Udagawa T, Shiozaki K, Kobayashi M, Kobayashi K. Accuracy of Oral Mucosal Thickness Measurements Using Spiral Computed Tomography. J Periodontol 2011; 82: 829-36.

24. Müller HP, Schaller N, Eger T, Heinecke A. Thickness of masticatory mucosa. J Clin Periodontol 2000; 27: 431-6. 